\title{
Exploring the Relationship of Competency, Management Best Practices, and Employee Performance in a Palm Oil Mill Company
}

\author{
Hermailinda Evianisa $^{1 *}$; Anggraini Sukmawati ${ }^{2}$; Alim Setiawan Slamet ${ }^{3}$ \\ ${ }^{1-3}$ Department of Management, Faculty of Economics and Management, Graduate School of Bogor Agricultural University \\ Jln. Raya Darmaga, IPB Graduate School Building, Bogor 16680, Indonesia

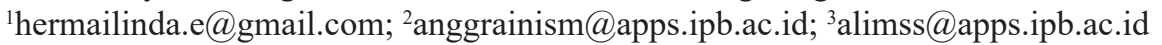

Received: $23^{\text {rd }}$ May 2020/ Revised: $20^{\text {th }}$ July 2020/ Accepted: $7^{\text {th }}$ September 2020

How to Cite: Evianisa, H., Sukmawati, A., \& Slamet, A. S. (2021). Exploring the Relationship of Competency, Management Best Practices, and Employee Performance in a Palm Oil Mill Company. Binus Business Review, 12(1), 8592. https://doi.org/10.21512/bbr.v12i1.6407

\begin{abstract}
In managing human resources, management is required to find appropriate competency development. The employees need to know what competency indicators they have and should have. It needs to be done to encourage the best practices provided by management to improve employee performance. The research aimed to identify the competency of human resources and management best practices related to advancing employee performance in a palm oil mill company. The research applied a quantitative approach. The studied company was Talopino palm oil mill unit in Seluma Regency, Bengkulu, owned by PT Perkebunan Nusantara VII Lampung (PTPN VII Lampung). The research was conducted from July to November 2019. The used data were primary and secondary data. Primary data were obtained by interviews and questionnaires with 76 employees in the company. The indicators were adapted from several previous researchers. The research analyzed the data using the Likert scale and Partial Least Square Structural Equation Modeling (PLS-SEM). The result shows three implications. First, competency affects employee performance in the palm oil mill company. Second, competency has an insignificant result on management best practices. Third, management best practices affect employee performance. The research can provide information to companies in enhancing the employees' competency with strategic steps in the era of globalization.
\end{abstract}

Keywords: employee competency, management best practices, employee performance, palm oil mill company

\section{INTRODUCTION}

Human resources in a company should have skills in their field. Employees' skills are an essential part of a company in the current era of globalization. Skills can be in the form of competency in each employee that is already existing and newly developed. Competency is related to the concept of an individual's ability to understand the work and give the best ability in the work activities (Glaesser, 2019). Competency is very needed in any workplace now. It is a part of a person's personality. It can predict behavior and performance extensively in all situations and job assignments (Spencer Jr \& Spencer, 1993). It must be a major part of enhancing the company so that human resources will become the highest priority and an essential investment (Van Esch, Wei, \& Chiang, 2018). It becomes part of the company in seeing the ability of its employees. Then, management can assess skills and create effective competency models to produce employees' competencies according to their capabilities (Al-Mannaee \& Ryan, 2018).

Personal competency is a measure of the basic ability of individuals who are born with it or form it by growing in different cultures in an organization. Hence, it can be oriented or implemented to the work and reflected in company performance that involves one's abilities (Shet, Patil, \& Chandawarkar, 2019). Personal competency can be seen through the six dimensions of the personal competency 
framework, according to Sanghi (2007). There are intellectual, personal, communication, interpersonal, leadership, and oriented to the result (result-oriented) competencies. Mapping personal competency is essential to assess what competency is needed and to what extent the company has that competency. Then, companies can analyze employee performance and achieve company goals.

At present, the business industry in the palm oil mill attracts many workers who have the ability (skill) and no ability (non-skill). The competency factor is needed in the company's operations, especially related to all operational works with tools and machines. The palm oil industry often experiences shocks with the ups and downs of the Crude Palm Oil (CPO) value, so companies have to improve the quality of their workforce. Moreover, the palm oil mill industry contributes significantly to the creation of large businesses.

One of the state-owned companies in the palm oil processing sector with its palm oil mill company is PT Perkebunan Nusantara VII Lampung (PTPN VII Lampung). The existing business unit occupied the eighth position in the palm kernel oil sales in 2018 . The sales rank can be seen in Table 1. It is based on realization and Rencana Kerja dan Anggaran Perusahaan (RKAP - work and budget planning of the company).

The drop in CPO world price has become a significant factor in affecting employee performance. PTPN VII Lampung needs to determine the right strategy in facing the low volume of kernel sales to increase its employees' enthusiasm for improving its performance. One of the strategies is that PTPN VII Lampung improves its palm oil business entities through the Cooperation Operational program. It is a collaboration in the operations with two or more companies in a business project. PTPN VII Lampung becomes the first PTPN company to conduct this program by establishing operational cooperation with several private companies or business partners. This strategy needs to be done to increase income from idle production. PTPN VII Lampung carries out the joint operation to optimize the idle factory capacity. An example is the Talopino palm oil mill unit in Seluma Regency, Bengkulu. This joint operation can improve its revenue (SCRIBD, 2019).

The Talopino palm oil mill unit is a new model of cooperation for other assets of PTPN VII Lampung. The joint operation, which is carried out with other companies, continues to use employees in the Talopino oil palm mill unit with the same machines and tools. Therefore, the involved companies are obliged to meet the Fresh Fruit Bunches (FFB) raw material for their production. The joint operation also places several supervisors to oversee the production process (SCRIBD, 2019).

Moreover, it is important to see what factors and implications of competency that the Talopino palm oil mill unit employees have. Besides that, it can be a basic reference in assessing the effectiveness of competency for employee performance, including which basic competency is needed at the Talopino palm oil mill unit to enhance employee performance. There are several previous studies on the relationship between competency and management best practices. Devika et al. (2020) found that not well-targeted policies resulted in conflict between organizations and human resources. Hence, it is important to implement good management practices.

Human resources management includes competency in recruitment, selection, performance appraisal, training, and compensation. In other words, research on human resource strategy can produce a resource management process with the right career development. It will play a major role as a first step in implementing a good basic competency management system to achieve company goals. Employee selection is expected to screen competent employees with career placements that match their competencies. According to Sanghi (2007), the right management policy in the process of receiving and providing competency training to improve performance will produce the desired quality and quantity for the company. Hence,

Table 1 The Ranking of Palm Kernel Oil Sales in 2018 (in Tons)

\begin{tabular}{llccc}
\hline No & Description & $\begin{array}{c}\text { Realization in } \\
\mathbf{2 0 1 7}\end{array}$ & $\begin{array}{c}\text { RKAP in } \\
\mathbf{2 0 1 8}\end{array}$ & $\begin{array}{c}\text { Realization in } \\
\mathbf{2 0 1 8}\end{array}$ \\
\hline 1 & PTPN I & 19.877 & 28.612 & 20.529 \\
2 & PTPN VI & 20.155 & 21.502 & 20.373 \\
3 & PTPN XIII & 39.135 & 69.749 & 18.182 \\
4 & PTPN II & 16.109 & 28.095 & 17.683 \\
5 & PTPN IV & 38.003 & 47.805 & 17.533 \\
6 & PTPN VIII & 9.450 & 2.718 & 11.515 \\
7 & PTPN XIV & 5.574 & 7.947 & 4.250 \\
$\mathbf{8}$ & PTPN VII & $\mathbf{1 . 4 2 5}$ & $\mathbf{2 . 7 1 8}$ & $\mathbf{2 . 4 5 0}$ \\
\hline
\end{tabular}

(Source: PT Perkebunan Nusantara III (Persero), 2018) 
this role can be seen from the efficiency of employee time and cooperative attitude in carrying out work activities.

The competency model describes the combination of knowledge, skills, and the quality and quantity of characteristics needed for employees to carry out their roles effectively in the organization. It can be used as a tool for human resource selection, critical training, and development determinants for employees, appraisal, and planning. Moreover, it is also a source of effective competency models by communicating management values and focusing on individual employee behavior to the employees. For example, competency-based assessment systems help distinguish the characteristics to establish and maintain company values. Good time management leads to the increased efficiency and productivity, stress reduction, and more (Sanghi, 2007). Seddighi and Mathew (2020) examined the measurement of human resource performance with the results of the quantity and quality of objects, time period, experience at work, and cooperative attitudes in influencing employee performance.

In managing human resources, management is required to find appropriate competency development. The employees need to know what competency indicators they have and should have. It needs to be done to encourage the best practices provided by management to improve employee performance. The research is conducted to identify the competence of human resources and management best practices related to improving employee performance in palm oil mill companies. The research is expected to provide information on indicators that affect competency. It is also to increase knowledge for management and the company in developing employee competencies and implementing effective management best practices to improve the employee performance in PTPN VII Lampung. It can also show what competencies are needed in improving employee performance related to what the company management has done.

Based on the literature reviews and the previous researches, the framework can be seen in Figure 1. Then, the research hypotheses are as follows.
H1 : Competency affects employee performance

H2 : Competency affects the management best practices

H3 : Management best practices affect employee performance

\section{METHODS}

The research applies a quantitative approach. The studied company is Talopino palm oil mill unit in Seluma Regency, Bengkulu owned by PTPN VII Lampung. The research was conducted from July to November 2019. The used data are primary and secondary. Primary data are obtained by interviews and questionnaires with 76 employees in the company. Meanwhile, the secondary data are gathered from documents, scientific journals, and previous reports.

In the questionnaire, the researchers use 45 competency assessment factors from Sanghi (2007) and 5 indicators for management best practices and 5 indicators for employee performance by De Waal and Van Der Heijden (2015). Those items explain the human resource management process. Then, the used measurement scale is the Likert scale.

The research also use the Partial Least Square Structural Equation Modeling (PLS-SEM) approach for model testing (Ali, Rasoolimanesh, Sarstedt, Ringle, \& Ryu, 2018). The analysis process is carried out in several stages, namely the outer model, inner model, and the relationship between variables.

\section{RESULTS AND DISCUSSIONS}

The respondents are employees of the joint operation in Talopino palm oil mill unit. They are dominated by male employees around $92 \%$. Most respondents are 50-60 years old (48\%). Senior high school graduates dominate the employees' education $(55 \%)$. Then, most respondents have long working experience around 21-25 years (33\%). Meanwhile, the length of tenure in the company is dominated by $6-10$ years, amounting to $32 \%$. The average income of employees is $2-4$ million per month $(57 \%)$ in Table 2.

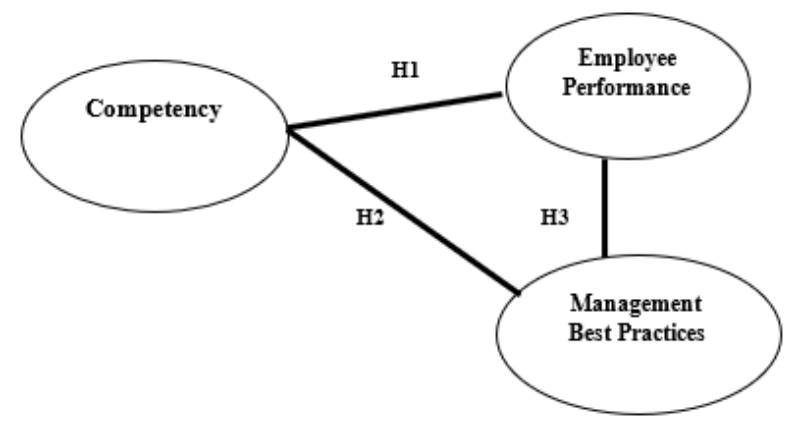

Figure 1 Research Model 
Table 2 Characteristics of the Respondents

\begin{tabular}{|c|c|c|}
\hline Characteristics & Description & Percentage \\
\hline \multirow[t]{3}{*}{ Gender } & Male & 92 \\
\hline & Female & 8 \\
\hline & Total & 100 \\
\hline \multirow[t]{4}{*}{ Age } & $50-60$ years old & 48 \\
\hline & 40 years old & 34 \\
\hline & 20-30 years old & 18 \\
\hline & Total & 100 \\
\hline \multirow[t]{6}{*}{ Education } & Primary School & 15 \\
\hline & Junior High School & 20 \\
\hline & Senior High School & 55 \\
\hline & Diploma 1-3 & 1 \\
\hline & $\mathrm{S} 1-\mathrm{S} 2$ & 9 \\
\hline & Total & 100 \\
\hline \multirow[t]{8}{*}{ Working experience } & $1-5$ years & 4 \\
\hline & $6-10$ years & 15 \\
\hline & $11-15$ years & 8 \\
\hline & 16-20 years & 22 \\
\hline & 21-25 years & 33 \\
\hline & 26-30 years & 17 \\
\hline & $>30$ years & 1 \\
\hline & Total & 100 \\
\hline \multirow[t]{9}{*}{ The length of tenure } & $<1$ years & 12 \\
\hline & $1-5$ years & 26 \\
\hline & $6-10$ years & 32 \\
\hline & $11-15$ years & 8 \\
\hline & $16-20$ years & 15 \\
\hline & $21-25$ years & 5 \\
\hline & $26-30$ years & 1 \\
\hline & $>30$ years & 1 \\
\hline & Total & 100 \\
\hline \multirow[t]{7}{*}{ Average income } & $<2$ million per month & 33 \\
\hline & $\begin{array}{l}2-4 \text { million per } \\
\text { month }\end{array}$ & 57 \\
\hline & $4-6$ million per month & 3 \\
\hline & $\begin{array}{l}6-10 \text { million per } \\
\text { month }\end{array}$ & 1 \\
\hline & $\begin{array}{l}10-15 \text { million per } \\
\text { month }\end{array}$ & 3 \\
\hline & $\begin{array}{l}>15 \text { million per } \\
\text { month }\end{array}$ & 3 \\
\hline & Total & 100 \\
\hline
\end{tabular}

The analysis process is carried out in several stages: outer model, inner model, and the relationship between variables. First, the outer model measures the latent variables using three stages. There are convergent validity, discriminant validity, and composite reliability. Table 3 shows the results.

Second, the inner model is performed using $\mathrm{R}$-squared in an independent construct. The model evaluation uses PLS using bootstrapping. The value of composite reliability is the R-squared of 0,95 for employee performance, 0,98 for competency, and 0,95 for management best practices (see Table 3). It means that high performance can be seen from and influenced by employee competency and management best practices.

Third, it is the influence of the relationship between variables analysis. The hypothesis test uses bootstrapping to see the t-value. The hypotheses are presented in Table 4. The measurement uses the statistical value of the t-table value with $n=76$ and $95 \%$ of the parameter values are more than $1,96$ (t-statistic $>1,96)$. Therefore, the obtained results show that competency influences employee performance with a significant value of 4,63. Between employee competency and management best practice, the obtained results show no effect with a significance of 0,18 . It is far from the needed parameter value. So, it is clear that the existing competency is not related to existing management best practices. It can be related to the effectiveness of the management best practices in this company itself so that it does not require special competency in carrying out its control. Then, the management best practices affect the employee performance with a significant value of 7,55.

The analysis test results for the Talopino palm oil mill unit with actual competency measurements show two significant variables (competency and management best practice). Figure 2 (see Appendix) shows the indicator with a higher value than loading factor Score $>0,70$. In the competency, there are 14 of 45 initial indicators that influence the employees' competency in the Talopino palm oil mill unit. It means that there are 14 possessed competency indicators by the employees. So clearly, there is only a little competency in the Talopino palm oil mill unit. However, the highest value shows several implications. The tenacity (X143) indicator has the value of 24,87 . It explains that the employees highly consider the importance of quality work results to satisfy customers. The other highest competency indicator is empowering (X133) with the value of 25,46 . The competency currently in Talopino palm oil mill unit is about how employees can have self-empowerment with their competency. The existing employees can empower the competency of the employee management.

Competency has a significant effect on employee performance. It becomes an essential factor with a high significance value. H1 is accepted. In employee performance, the highest actual indicator is in the output quantity (Y11), with an indicator value of 50,48. The best orientation in achieving superior performance is the number of outputs that can be produced. The result is in line with Podmetina, Soderquist, Petraite, and Teplov, (2018). The competency becomes a strong influence that employees will show their best performance in satisfying consumers. Hence, it will 
improve employee performance. The employees can empower their competency by providing good work results and mastery of their respective fields and work portions. The result is also supported by Glass and Metternich (2020) and Devika et al. (2020). Competency can be a measuring tool in improving employee performance with the right strategy and good planning. So, competency is important in enhancing employee performance in the Talopino palm oil mill unit.

Next, competency has an insignificant result on management best practices. Competency does not affect management best practices in the Talopino palm oil mill unit. $\mathrm{H} 2$ is rejected. The t-value of the relationship is less than 1,96 . The result is in line with Shivanjali, Singh, and Singh (2019) that management best practices did not affect competency. However, several previous researchers have different results. Nkondola and Van Deuren (2017) stated that the management best practices are influenced by competency in its application in an organizational environment. Moreover, Goktepe et al. (2018) agreed that competency influenced management best practices. A good management best practices contributed to improving the quality of work and achievement of company goals. Hence, the support from superiors was a factor in improving employee performance. The research result shows that management best practices are not influenced by competency. In carrying out the activities, competency is only considered a formality in carrying out the management best practices in the Talopino palm oil mill unit.

Moreover, the management best practices influence employee performance in the Talopino palm oil mill unit. It has a higher t-value than 1,96. The effect of management best practices on employee performance is 7,55 > 1,96 (Table 4). The management best practices can improve employee performance. H3 is accepted. The result is in line with Waal and Heijden (2015) that an organization knew which management best practices affected employee performance. Similarly, Devika et al. (2020) suggested that management best practices improved employee performance. Employees in Talopino palm oil mill unit are considered sufficient to pay great attention to the management best practices, especially on the performance appraisal with a high significance value. In addition, the highest result is the training factor (X24) with a score of 45,64 . It shows the actualization in management best practices is training. Hence,

Table 3 Outer Model Test Results

\begin{tabular}{lll}
\hline Outer Model & Criteria & The result in Talopino palm oil mill unit \\
\hline $\begin{array}{l}\text { Convergent } \\
\text { Validity }\end{array}$ & Loading factor score $\geq 0,70$ & $\begin{array}{l}\text { The results meet the requirements and have a bigger } \\
\text { loading factor score than } 0,70 .\end{array}$ \\
& $\begin{array}{l}\text { Cross loading score and } \\
\text { construct correlation } \geq \text { other } \\
\text { construct measurements }\end{array}$ & $\begin{array}{l}\text { Requirements are fulfilled by loading the bigger value } \\
\text { of the intended construct than the loading values with } \\
\text { other constructs. }\end{array}$ \\
$\begin{array}{l}\text { Discriminant } \\
\text { Validity }\end{array}$ & $\begin{array}{l}\text { Average Variance Extracted } \\
\text { (AVE) score } \geq 0,50\end{array}$ & $\begin{array}{l}\text { The AVE value results meet the requirements with a } \\
\text { competency result of } 0,52, \text { management best practices } \\
\text { of } 0,72, \text { and employee performance of } 0,77 . ~\end{array}$ \\
$\begin{array}{l}\text { Composite } \\
\text { Reliability }\end{array}$ & $\begin{array}{l}\text { Composite Reliability Score } \geq \\
\text { The value of composite reliability is } 0,98 \text { for } \\
\text { competency, } 0,95 \text { for management best practice, and } \\
0,95 \text { for employee performance. }\end{array}$ \\
\hline
\end{tabular}

(Source: Processed Data, 2020)

Table 4 Path Coefficient Results

\begin{tabular}{lccc}
\hline Variable & \multicolumn{3}{c}{ Talopino Palm Oil Mill Unit } \\
\cline { 2 - 4 } & Original Sample & T-Statistic & Hypothesis \\
\hline $\begin{array}{l}\text { Competency } \rightarrow \text { employee } \\
\text { performance }\end{array}$ & 0,39 & $\mathbf{4 , 6 3}$ & Significant \\
$\begin{array}{l}\text { Management best practices } \rightarrow \\
\text { employee performance }\end{array}$ & 0,61 & $\mathbf{7 , 5 5}$ & Significant \\
$\begin{array}{l}\text { Competency } \rightarrow \text { management best } \\
\text { practices }\end{array}$ & 0,01 & 0,18 & Insignificant \\
\hline
\end{tabular}


training is the best thing that management can do in improving employee performance.

The employees in the Talopino palm oil mill unit emphasize technical competency. It relates to the use of machines and tools. Mahmood, Hee, Yin, and Hamli, (2018) mentioned that employees' competencies were seen from the increase in employee performance. Currently, there was good cooperation with attractive work programs. Meanwhile, Spencer and Spencer (1993) found that competency was a part of oneself and forever in one's personality. It predicted the behavior and performance widely in all situations and job assignments. However, Sanghi (2007) found that existing competency within the company had not yet fully been brought up, so competency assessments had to be done starting from employees' habits and characters.

Personal competency is essential in determining a good strategy for the employees. Hence, employees can give their best performance, which will impact increasing their performance on the company (Patil, Ulle, \& Varma, 2018). Moreover, the company needs to read the competency of its employees. The importance to always evaluate employee competency can be a consideration for the company. The management, especially related to human resources, is required to the core competency that is owned or newly formed in the employees (Seddighi \& Mathew, 2020). By knowing employees' competencies, management will make a practical decision to develop suitable skills and career paths.

The running competency should follow the owned provisions with additional aspects of exploring basic and formed competency in employees. Management that has been running well must continue to improve its quality, especially in managing the employees' competencies. Existing competency in work still needs to be considered in their implementation. Planning the improvement of company capability needs to be done by focusing on human resources as a corporate asset. Employees need to increase their needs with intensive and targeted training (Otoo \& Mishra, 2018).

The results show that the competency of the Talopino palm oil mill unit is influential on employee performance. It can also be influenced by employees' age (50-60 years with 48\%) as they have long working experience. Moreover, the management should consider the vulnerable young productive age that is not enough (only 18\%). The difference is quite large. Employee regeneration needs to be considered.

Only 14 of 45 competency indicators are shown in the result. It implies that the actual competency gap in employees is quite visible. The head office can give more attention to training and certification that are beneficial for the employees. Providing training and certification should be done more frequently. The competency needs to be improved.

Similarly, management best practices need to be maintained in controlling the improvement of employee performance. It is related to the importance of good management best practices in assessing central management employees. Management must evaluate each employee's commitment and competency periodically based on the used references, such as the competency dictionary. However, management needs to give more attention to employees for their contribution to the company and their competency. Then, central control needs to be more active to monitor the development of employee competencies.

Competency coupled with the improved management best practices will increase employee performance. The collaboration of the two variables will be outstanding if it gets more attention from management. The existing management best practices have run quite well on employee performance. Hence, management can focus more on improving employees' competencies and adding more competency factors to support employee performance.

\section{CONCLUSIONS}

The palm oil mill company should give attention to the competency of their employees. Competency is related to improving employee performance and selfempowerment. Based on the results, it can be concluded that an improvement in employee competency is needed for palm oil mill employees. The lack of owned competency indicators by employees needs to be improved by company management to improve employee performance further. In addition, there is a relationship between managerial functions and employee performance in terms of increasing employee performance. The management best practices have a great influence on employee performance side by side with competency. The management best practices, which have a significant influence, indicates that it is running quite effectively. It is expected that good management best practices can motivate employees to display their competencies so that their performance can continue to increase. It is related to employees' confidence in employees' experience and position, who consider the manager's function as a planner and supervision of employee performance.

The management best practices run effectively in improving employee performance, so it is essential to maintain results and further improve management best practices to get maximum results in the future. Management in the palm oil mill needs to improve the employees' competencies, think more about their employees' competency framework, and start Training Needs Analysis (TNA). Hence, the management can identify competency factors that need to improve more and who needs to be trained. It is expected that future researchers will focus on how to improve the competency of palm oil mill employees in the future. Future research can also examine the whole palm oil mill company to obtain a big picture of how competency plays a vital role for employees.

The limitation of the research is the lack of research related to the competencies of palm oil mill employees using the actual competency 
factors. It is associated with the implementation of the management best practices, especially human resources, in improving the performance of palm oil mill employees. Therefore, there is a need for a more detailed discussion through structured interviews. It can explore more about other factors in management best practices that are influenced or seen through the assessment of competency factors.

\section{REFERENCES}

Ali, F., Rasoolimanesh, S. M., Sarstedt, M., Ringle, C. M., \& Ryu, K. (2018). An assessment of the use of Partial Least Squares Structural Equation Modeling (PLSSEM) in hospitality research. International Journal of Contemporary Hospitality Management, 30(1), 514538. https://doi.org/10.1108/IJCHM-10-2016-0568

Al-Mannaee, N. S., \& Ryan, J. C. (2018). Examining a competency model of workplace learning: An assessment of participants' reactions. International Journal of Work Organisation and Emotion (IJWOE), 9(1), 107-124. https://doi.org/10.1504/ IJWOE.2018.091346

De Waal, A., \& Van Der Heijden, B. I. (2015). The role of performance management in creating and maintaining a high-performance organization. Journal of Organization Design, 4(1), 1-11.

Devika, Raj, P., Venugopal, A., Thiede, B., Herrmann, C., \& Sangwan, K. S. (2020). Development of the transversal competencies in learning factories. Procedia Manufacturing, 45, 349-354. https://doi. org/10.1016/j.promfg.2020.04.031

Glaesser, J. (2019). Competence in educational theory and practice: A critical discussion. Oxford Review of Education, 45(1), 70-85. https://doi.org/10.1080/03 054985.2018 .1493987

Glass, R., \& Metternich, J. (2020). Method to measure competencies-A concept for development, design and validation. Procedia Manufacturing, 45, 37-42. https://doi.org/10.1016/j.promfg.2020.04.056

Goktepe, N., Turkmen, E., Badir, A., Hayta, O., Yakar, H. K., \& Buyukgonenc, L. A. (2018). Development of managerial competencies for first-level nurse managers in Turkey. International Journal of Caring Sciences, 11(2), 1096-1102.

SCRIBD. (2019). Surat perjanjian jual beli Tandan Buah Segar (TBS) kelapa sawit antara PTPN VII Unit Talopino dengan PT. Bengkulu Sawit Lestari. Retrieved from https://id.scribd.com/ document/405884511/Kontrak-TBS-Januari-2019pdf

Mahmood, R., Hee, O. C., Yin, O. S., \& Hamli, M. S. H. (2018). The mediating effects of employee competency on the relationship between training functions and employee performance. International Journal of Academic Research in Business and Social
Sciences, 8(7), 664-676. https://doi.org/10.6007/ IJARBSS \%2FV8-I7\%2F4410

Nkondola, A. A., \& Van Deuren, R. (2017). Human resource management challenges in technical and vocational education in developing countries: The case study of technical institutions in Tanzania. International Journal of Business and Social Science, 8(2), 156162.

Otoo, F. N. K., \& Mishra, M. (2018). Measuring the impact of Human Resource Development (HRD) practices on employee performance in small and medium scale enterprises. European Journal of Training and Development, 42(7/8), 517-534. https://doi. org/10.1108/EJTD-07-2017-0061

Patil, K., Ulle, R. S., \& Varma, A. J. (2018). Competency mapping at Seiren India Private Limited, Kadakola, Mysore. Journal of Emerging Technologies and Innovative Research (JETIR), 5(8), 799-803.

Podmetina, D., Soderquist, K. E., Petraite, M., \& Teplov, R. (2018). Developing a competency model for open innovation: From the individual to the organisational level. Management Decision, 56(6), 1306-1335. https://doi.org/10.1108/MD-04-2017-0445

PT Perkebunan Nusantara III (Persero). (2018). Akselerasi transformasi perkebunan - Annual Report 2018. Retrieved from https://www.holding-perkebunan. com/laporan-tahunan-2018

Sanghi, S. (2007). The handbook of competency mapping: Understanding, designing and implementing competency models in organizations $\left(2^{\text {nd }} \mathrm{ed}\right) .(\mathrm{pp}$. 3-176). SAGE Publications.

Seddighi, H. R., \& Mathew, S. (2020). Innovation and regional development via the firm's core competence: Some recent evidence from North East England. Journal of Innovation \& Knowledge, 5(4), 219-227. https://doi.org/10.1016/j.jik.2019.12.005

Shet, S. V., Patil, S. V., \& Chandawarkar, M. R. (2019). Competency based superior performance and organizational effectiveness. International Journal of Productivity and Performance Management, 68(4), 753-773. https://doi.org/10.1108/ IJPPM-03-2018-0128

Shivanjali, Singh, M., \& Singh, T. (2019). Competency mapping, a strategic perspective in employee retention. International Journal of Recent Technology and Engineering (IJRTE), 8(2), 3890-3898.

Spencer Jr., L. M., \& Spencer, S. M. (1993). Competence at work: Models for superior performance. Wiley.

Van Esch, E., Wei, L. Q., \& Chiang, F. F. (2018). Highperformance human resource practices and firm performance: The mediating role of employees' competencies and the moderating role of climate for creativity. The International Journal of Human Resource Management, 29(10), 1683-1708. https:// doi.org/10.1080/09585192.2016.1206031 


\section{APPENDIX}

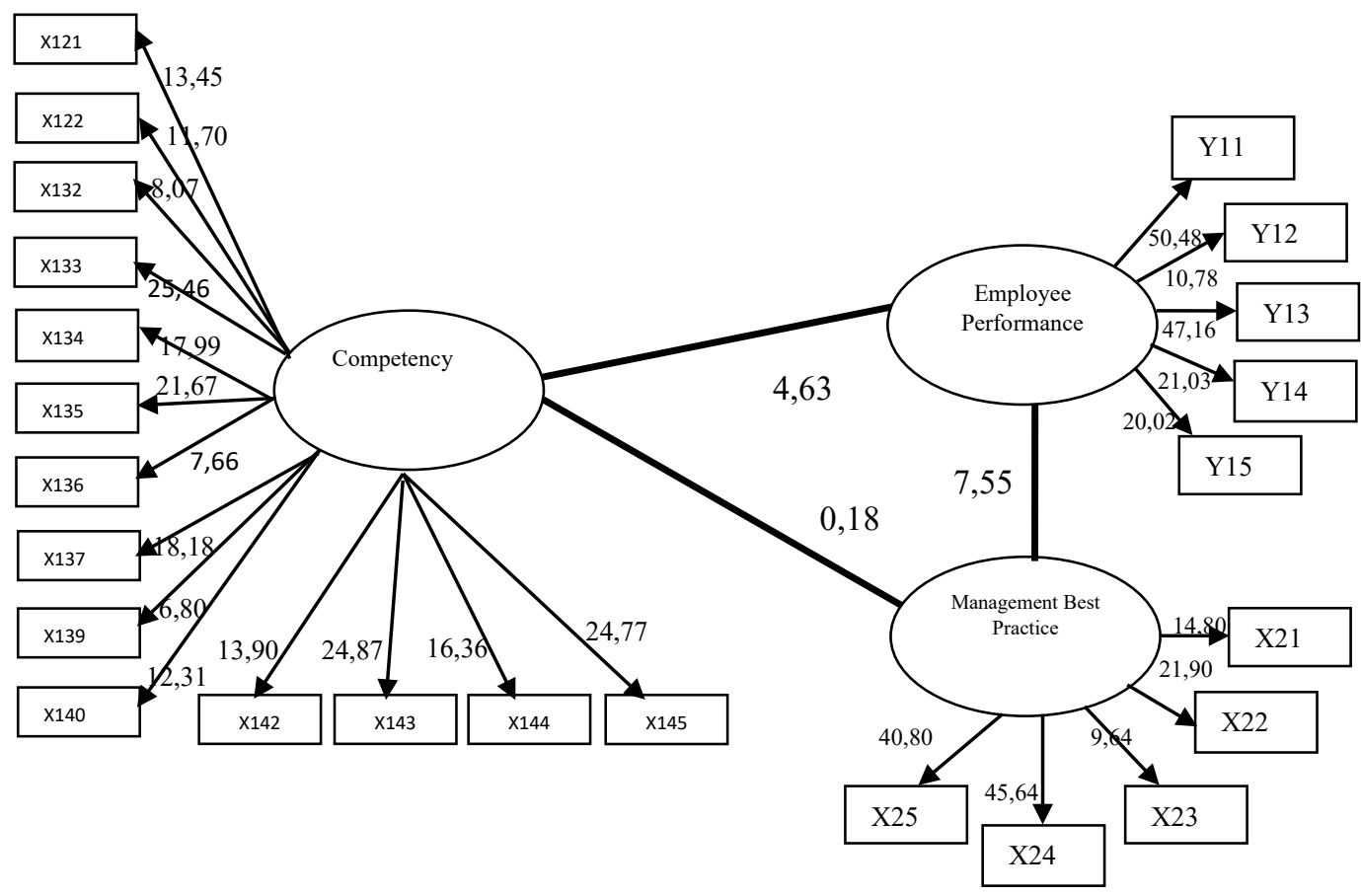

Description:

Competency:

X121: Reading

X122: Written

communication

X132: Organizing

X133: Empowering

X134: Appraising

X135: Motivating other

X136: Developing others

X137: Leading

X139: Decisivenes

X140: Business sense

X142: Concern for excellence

X143: Tenacity

X144: Initiative

X145: Customer-oriented

Management Best
Practices
X21: Recruitment
and selection
X22: Performance
evaluation
X23: Compensation
X24: Training
X25: Career
development

development

Figure 2 The Indicator Values in Each Variable 